\title{
Anthropometric Characteristics of Young Women in Yakutia, Depending on the Type of Sexual Dimorphism and Ethnos
}

\author{
Vilyuia A. Alekseeva, PhD*; Alla B. Guryeva, PhD; Palmira G. Petrova, PhD, ScD; \\ Alena A. Osinskaya, PhD; Lena K. Turkebaeva, PhD \\ M. K. Ammosov North-Eastern Federal University \\ Yakutsk, the Republic of Sakha (Yakutia), Russia
}

\begin{abstract}
The aim of this study was to assess the anthropometric data of girls and young women in Yakutia, depending on the type of sexual dimorphism and ethnos. The study included 2,081 girls and young women aged from 16 to 20 years. All those examined were born and permanently resided in the territory of the Republic of Sakha (Yakutia); among them there were 1284 Yakuts and 797 Russians. Anthropometric measurements were carried out according to the method of V.V. Bunak (1941), adopted in the Institute of Anthropology of MSU. Absolute values of the main components of the body (the total amount of fat, muscle tissue, bone tissue) were calculated by the formula Matiegka (1921). The body type was determined in accordance with the Tanner index. Statistical analysis was performed using statistical software package SPSS version 17.0 (SPSS Inc, Chicago, IL) The data obtained, depending on the type of sexual dimorphism, indicate the different maturation rates of the morphofunctional structures in Yakut and Russian women in the extreme natural climatic conditions of Yakutia. (International Journal of Biomedicine. 2017;7(3):231-235.)
\end{abstract}

Key Words: somatotype $\bullet$ human physique $•$ Tanner index • Yakutia

\section{Introduction}

The history of classification and analysis of the human physique can be traced back to ancient times. Hippocrates, a great Greek philosopher and physician of the fifth century $\mathrm{BC}$, described two different types of bodies. The first he called habitus phthisicus, which was long and thin, and dominated by a vertical dimension; the second he called habitus apoplecticus, whose main physical characteristic was a short, thick body that was strong in the horizontal dimension. While the former were assumed to have a greater susceptibility to tuberculosis, the latter were very much prone to the diseases of the cardiovascular system. In the 1940s, the famous psychologist William Sheldon proposed the word "somatotype" to describe a body-type using his method of classifying the human physique. ${ }^{(1)}$ He claimed that there are 3 such somatotypes: endomorphy, mesomorphy, and ectomorphy. Most people are unique combinations of these three body types. Sheldon stands out as the pivotal

*Corresponding author: Vilyuia A. Alekseeva, PhD. M. K. Ammosov North-Eastern Federal University, Yakutsk, the Republic of Sakha (Yakutia),Russia.E-mail: viljen1974@mail.ru researcher in this field even though his method is not widely used. In biomedical practice, there are many methods of somatotyping, among which the method of J.Tanner is most suitable for determining the type of physique of women. ${ }^{(2)}$ Sexual dimorphism can be characterized as gynecomorphic, mesomorphic and andromorphic somatotypes.

Preserving the health of young women, as future mothers, is one of the priorities of modern medicine. According to a number of authors, the adolescent period in the ontogenetic cycle of a person is characterized by the stability of physiological parameters and the development of the reproductive system. ${ }^{(3,4)}$ At the same time, there are some studies devoted to the ethno-territorial features in the formation of the morphofunctional status of human. Researchers note the different rates of physical development and reproductive system development among residents of different regions and different ethnic groups. ${ }^{(5,6)}$

Currently, a number of studies are being carried out in Yakutia aimed at studying the population from the standpoint of biomedical anthropology. ${ }^{(7,8)}$ However, the morphofunctional features of girls of different ethnic groups living in the extreme climatic conditions of Yakutia have not been studied enough. That lack determined the relevance of this study. 
The aim of this study was to assess the anthropometric data of girls and young women in Yakutia, depending on the type of sexual dimorphism and ethnos.

\section{Materials and Methods}

The study included 2,081 girls and young women aged from 16 to 20 years. All those examined were born and permanently resided in the territory of the Republic of Sakha (Yakutia) $(\mathrm{RS}(\mathrm{Y}))$; among them there were 1284 Yakuts and 797 Russians.

In accordance with the age period of human ontogeny, the examined persons belonged to the youthful period of human development (16-20 years). The examination was not conducted during pregnancy, or in the presence of acute diseases and exacerbation of chronic diseases at the time of examination. Ethnicity of the study participants was determined based on personal data. The examined persons were full-time and part-time students of higher and secondary special educational institutions.

Anthropometric measurements were carried out according to the method of V.V. Bunak, adopted in the Institute of Anthropology of MSU.(9) Body length (BL) was measured using a Martin metal anthropometer with an accuracy of $0.1 \mathrm{~cm}$. Body weight $(\mathrm{BW})$ was measured without clothing using medical scales with an accuracy of $50 \mathrm{~g}$. The skinfold thickness was measured using the Holtain Tanner/Whitehouse Skinfold Caliper (United Kingdom) with a contact surface area of $90 \mathrm{~mm}^{2}$ and a pressure of $10 \mathrm{~g} / \mathrm{mm}^{2}$ with an accuracy of $1 \mathrm{~mm}$. In addition, we measured the skin fat folds of the shoulder (the front and back surfaces), forearm, back, chest, abdomen, hip and lower leg. The circumference dimensions of shoulder, forearm, wrist, hip, lower leg, thorax, buttocks and girth over the ankles were determined using centimetric tape. The diameters of the shoulders and the pelvis were measured with a large caliber compass; the distal diameters of the shoulder, wrist, hip, and ankle with a sliding compass. The accuracy of the instruments used was verified after every 100 measurements, using a special calibration block.

The body surface area was calculated by Isaacson's method. ${ }^{(10)}$ Absolute values of the main components of the body (the total amount of fat, muscle tissue, bone tissue) were calculated by the formula Matiegka (1921). ${ }^{(11)}$

The total amount of fat was determined by the formula:

$$
D=d \times S \times k \text {, where }
$$

D - Total amount of fat $(\mathrm{kg})$

$\mathrm{d}$ - Average skin and subcutaneous adipose layer

thickness $(\mathrm{mm}), \mathrm{S}$ - body surface $\left(\mathrm{cm}^{2}\right)$,

$\mathrm{k}$ - Constant equal to 0.13

The average skin and subcutaneous adipose layer thickness was calculated according to the formula:

$$
d=\frac{d_{1}+d_{2}+d_{3}+d_{4}+d_{5}+d_{6}+d_{7}+d_{3}}{16} \text {, where }
$$

d1- $d 8$ - thickness of the skin fat folds of the shoulder (the front and back surfaces) forearm, back, abdomen, hip, lower leg and chest ( $\mathrm{mm})$.
The amount of muscle tissue was determined by the formula:

$$
M=L \times r^{2} \times k, \text { where }
$$

$\mathrm{M}$ - Absolute mass of muscle tissue $(\mathrm{kg})$

L- Body length $(\mathrm{cm})$

$r$ - Average value of the circumference dimensions of the shoulder, forearm, hip, lower leg without

skin and subcutaneous adipose layer thickness $(\mathrm{cm})$;

$\mathrm{r}=\sum$ girths (shoulder, forearm, hip, lower leg)/25.12-

$-\sum$ skin and subcutaneous adipose layer thickness

(shoulder, forearm, hip, lower leg)/100

k- Constant equal to 0.5

The absolute mass of bone tissue was calculated by the formula:

$$
Q=L \times O^{2} \times k \text {, where }
$$

$\mathrm{Q}$ - Absolute mass of the skin tissue $(\mathrm{kg})$

$\mathrm{L}$ - Body length $(\mathrm{cm}), \mathrm{O}^{2}$ - square of the average value of the distal diameters of the shoulder, forearm, hip, and lower leg

$\mathrm{k}$ - Constant equal to 1.2

To compare the relative values of the body components, the values of the components as a percentage of the body weight were determined.

The body type was determined in accordance with the Tanner index (sexual dimorphism index, ISD), ${ }^{(12)}$ calculated by the formula:

$$
I S D=3 \times B A D-I P D \text {, where }
$$

BAD - bisacromial diameter (shoulder width), cm;

IPD - Intercristal pelvic diameter, $\mathrm{cm}$.

The values of ISD $<73.1$ characterized the gynomorphic body type; ISD 73.1-82.1 the mesomorphic body type; and ISD $>82.1$ the andromorphic body type.

The study protocol was reviewed and approved by the Ethics Committee of Yakut Research Centre for Complex Medical Problems of the Siberian Branch of the RAS. Written informed consent was obtained from each patient

Statistical analysis was performed using statistical software package SPSS version 17.0 (SPSS Inc, Chicago, IL). Representativeness of the sample size was determined by the formula: ${ }^{(13)}$

$$
N=z^{2} \times p(1-p) / e^{2} \text {, where }
$$

$$
\begin{aligned}
& \mathrm{z} \text { - a } 95 \% \text { confidence Level (as a } \mathrm{z} \text {-score) } \\
& p \text { - percentage Value (as a decimal) } \\
& \text { e- margin of error (as a decimal) } \pm 5 \% \\
& \mathrm{~N} \text { - population size }
\end{aligned}
$$

Variables were presented as median and interquartile ranges (IQR). The Kruskal Wallis test was used to compare medians among comparison groups. Categorical variables were analyzed using the Chi-square test with the Yates' correction. A probability value of $P<0.05$ was considered statistically significant.

\section{Results and Discussion}

$\mathrm{BL}$ and body weight $\mathrm{BW}$ of the examined girls and young women of the Yakut and Russian nationality were 
Yakut, $159.5 \mathrm{~cm}$ [156.2;163.5] and $52.0 \mathrm{~kg}[48.0 ; 57.0]$; and Russian, $163.6 \mathrm{~cm}[157.0 ; 166.8]$ and $56.0 \mathrm{~kg}$ [50.0;60.0].

Among the Yakut women, we found the gynomorphic type in $19.3 \%$ of cases, the mesomorphic type in $72.7 \%$ of cases, and the andromorphic type in $8.0 \%$ of cases; among Russian women: $16.0 \%, 70.5 \%$, and $3.5 \%$, respectively (Tables 1 and 2).

In this period of human age, according to a number of scientists, there are no longer any age-related body transformations. ${ }^{(3,4)}$ At the same time, there are scientific data about the possible immaturity of morphological structures and the unfinished processes of constitution formation in adolescent girls. ${ }^{(14)}$ Studies of anthropometric indices and rates of development of secondary sexual characteristics of Yakut girls testify to later terms of sexual and physical development in comparison with the average indicators of other regions of Russia. ${ }^{[6,15]}$

Thus, BL and BW of Yakut women were significantly $(P<0.001)$ less than those of Russian women in Yakutia, which is consistent with the conclusions of other researchers on the smaller dimensions of representatives of Mongoloid ethnic groups in comparison to Caucasians. ${ }^{(6,17)}$
An analysis of the distribution of body types according to the Tanner index revealed that mesomorphic body type dominates $(72.7 \%$ in Yakuts and $70.5 \%$ in Russians) in both ethnic groups. The proportion of mesomorphic and gynomorphic types, depending on the ethnos, did not differ significantly. The extreme variant of sexual dimorphism in the form of andromorphy was smaller in both ethnic groups, but it was more often found among Russian women than among Yakut women $\left(\chi^{2}=13.313, P<0.01\right)$.

A similar distribution of body types was observed among young women in other regions of Russia: Caucasian women of the Baikal region (Irkutsk) ${ }^{(18)}$ and women of Khakassia. ${ }^{(5)}$ At the same time, among students of the Voronezh State Medical Academy named after N.N. Burdenko, the gynomorphic and mesomorphic types were determined in most cases with the same frequency. ${ }^{(14)}$

Our study revealed that the parameters of overall dimensions, shoulder and pelvis diameters, and absolute and relative parameters of the body components of Yakut women of different body types did not differ significantly. The obtained data testify to later physical and sexual development among Mongoloid women. ${ }^{([5,8)}$

Table 1.

Anthropometric data of the Yakut girls and young women by Tanner index

\begin{tabular}{|c|c|c|c|}
\hline \multirow[t]{2}{*}{ Variable } & $\begin{array}{c}\text { Gynomorphic body type } \\
\text { Me [LQ; UQ] } \\
(\mathrm{n}=248)\end{array}$ & $\begin{array}{c}\text { Mesomorphic body type } \\
\text { Me [LQ; UQ] } \\
(\mathrm{n}=933)\end{array}$ & $\begin{array}{l}\text { Andromorphic body type } \\
\text { Me [LQ; UQ] } \\
(\mathrm{n}=103)\end{array}$ \\
\hline & 1 & 2 & 3 \\
\hline \multirow{2}{*}{ Body length, cm } & $160.0[155.4 ; 164.0]$ & $159.4[156.4 ; 163.2]$ & $158.0[155.2 ; 164.6]$ \\
\hline & \multicolumn{3}{|c|}{$H=0.434 ; P=0.805$} \\
\hline \multirow{2}{*}{ Body weight, kg } & $52.0[48.0 ; 56.5]$ & $52.0[48.0 ; 57.0]$ & $50.0[48.0 ; 56.0]$ \\
\hline & \multicolumn{3}{|c|}{$H=1.154 ; P=0.562$} \\
\hline \multirow{2}{*}{$\begin{array}{l}\text { Shoulder diameter, } \\
\mathrm{cm}\end{array}$} & $34.0[33.2 ; 34.5]$ & $34.8[33.5 ; 35.5]$ & $35.0[33.5 ; 36.0]$ \\
\hline & \multicolumn{3}{|c|}{$H=1.240 ; P=0.538$} \\
\hline \multirow{2}{*}{$\begin{array}{l}\text { Intercristal pelvic diameter, } \\
\mathrm{cm}\end{array}$} & $27.0[25.4 ; 28.0]$ & $27.0[26.0 ; 28.0]$ & $27.0[26.0 ; 28.0]$ \\
\hline & \multicolumn{3}{|c|}{$H=1.895 ; P=0.388$} \\
\hline \multicolumn{4}{|c|}{ Body components } \\
\hline \multirow{2}{*}{$\begin{array}{l}\text { Absolute value of fat mass, } \\
\mathrm{kg}\end{array}$} & $14.46[11.85 ; 16.70]$ & $14.37[11.84 ; 16.89]$ & $14.60[11.63 ; 18.40]$ \\
\hline & \multicolumn{3}{|c|}{$H=0.472 ; P=0.790$} \\
\hline \multirow{2}{*}{ Body fat percentage, $\%$} & $27.49[24.13 ; 30.46]$ & $27.43[24.00 ; 30.82]$ & $28.86[24.80 ; 32.04]$ \\
\hline & \multicolumn{3}{|c|}{$H=3.199 ; P=0.202$} \\
\hline \multirow{2}{*}{$\begin{array}{l}\text { Absolute mass of muscle } \\
\text { tissue, } \mathrm{kg}\end{array}$} & $20.44[18.08 ; 22.47]$ & $20.46[18.69 ; 23.20]$ & $20.90[19.06 ; 23.35]$ \\
\hline & \multicolumn{3}{|c|}{$H=2.955 ; P=0.228$} \\
\hline \multirow{2}{*}{$\begin{array}{l}\text { Muscle tissue percentage, } \\
\%\end{array}$} & $38.72[35.11 ; 42.15]$ & $39.51[36.99 ; 42.20]$ & $41.43[38.16 ; 42.70]$ \\
\hline & \multicolumn{3}{|c|}{$H=5.194 ; P=0.074$} \\
\hline \multirow{2}{*}{$\begin{array}{l}\text { Absolute value of bone } \\
\text { mass, } \mathrm{kg}\end{array}$} & $7.83[7.09 ; 8.83]$ & $7.95[7.23 ; 8.76]$ & $8.04[7.43 ; 8.76]$ \\
\hline & \multicolumn{3}{|c|}{$H=2.019 ; P=0.364$} \\
\hline \multirow{2}{*}{ Bone mass percentage, $\%$} & $15.00[13.62 ; 16.60]$ & $15.50[14.00 ; 16.62]$ & $15.80[14.50 ; 16.70]$ \\
\hline & \multicolumn{3}{|c|}{$H=5.273 ; P=0.072$} \\
\hline
\end{tabular}


Table 2.

Anthropometric data of the Russian girls and young women by Tanner index

\begin{tabular}{|c|c|c|c|}
\hline \multirow[t]{2}{*}{ Variable } & $\begin{array}{c}\text { Gynomorphic body type } \\
\text { Me [LQ; UQ] } \\
(\mathrm{n}=127)\end{array}$ & $\begin{array}{c}\text { Mesomorphic body type } \\
\text { Me [LQ; UQ] } \\
(\mathrm{n}=562)\end{array}$ & $\begin{array}{c}\text { Andromorphic body type } \\
\text { Me [LQ; UQ] } \\
(\mathrm{n}=108)\end{array}$ \\
\hline & 1 & 2 & 3 \\
\hline \multirow{2}{*}{ Body length, cm } & $163.0[155.5 ; 164.8]$ & $163.2[157.0 ; 166.8]$ & $164.8[163.1 ; 170.6]$ \\
\hline & \multicolumn{3}{|c|}{$H=27.134 ; P<0.001$} \\
\hline \multirow{2}{*}{ Body weight, kg } & $50.0[49.0 ; 62.0]$ & $55.4[51.0 ; 59.0]$ & $58.0[55.0 ; 61.0]$ \\
\hline & \multicolumn{3}{|c|}{$H=28.205 ; P<0.001$} \\
\hline \multirow{2}{*}{ Shoulder diameter, $\mathrm{cm}$} & $32.4[32.0 ; 33.0]$ & $35.0[34.0 ; 35.0]$ & $37.0[36.2 ; 37.5]$ \\
\hline & \multicolumn{3}{|c|}{$H=324.206 ; P<0.001$} \\
\hline \multirow{2}{*}{$\begin{array}{l}\text { Intercristal pelvic diameter, } \\
\mathrm{cm}\end{array}$} & $26.0[25.5 ; 27.8]$ & $27.0[26.0 ; 27.2]$ & $27.0[25.2 ; 29.2]$ \\
\hline & \multicolumn{3}{|c|}{$H=5.764 ; P=0.056$} \\
\hline \multicolumn{4}{|c|}{ Body components } \\
\hline \multirow{2}{*}{$\begin{array}{l}\text { Absolute value of fat mass, } \\
\mathrm{kg}\end{array}$} & $14.36[9.34 ; 17.06]$ & $14.10[11.28 ; 17.70]$ & $16.21[12.83 ; 17.71]$ \\
\hline & \multicolumn{3}{|c|}{$H=19.634 ; P<0.001$} \\
\hline \multirow{2}{*}{ Body fat percentage, $\%$} & $25.53[18.67 ; 29.08]$ & $25.78[21.60 ; 30.74]$ & $27.88[24.59 ; 29.48]$ \\
\hline & \multicolumn{3}{|c|}{$H=6.873 ; P=0.032$} \\
\hline \multirow{2}{*}{$\begin{array}{l}\text { Absolute mass of muscle } \\
\text { tissue, } \mathrm{kg}\end{array}$} & $21.63[19.83 ; 24.02]$ & $23.32[20.86 ; 25.11]$ & $24.35[21.08 ; 26.10]$ \\
\hline & \multicolumn{3}{|c|}{$H=10.700 ; P=0.010$} \\
\hline \multirow{2}{*}{$\begin{array}{l}\text { Muscle tissue percentage, } \\
\%\end{array}$} & $42.60[40.14 ; 46.26]$ & $41.27[38.64 ; 42.83]$ & $44.10[42.83 ; 47.50]$ \\
\hline & \multicolumn{3}{|c|}{$H=19.739 ; P<0.001$} \\
\hline \multirow{2}{*}{$\begin{array}{l}\text { Absolute value of bone } \\
\text { mass, } \mathrm{kg}\end{array}$} & $7.88[6.71 ; 9.21]$ & $8.38[7.45 ; 9.21]$ & $9.06[8.57 ; 9.55]$ \\
\hline & \multicolumn{3}{|c|}{$H=39.593 ; P<0.001$} \\
\hline \multirow{2}{*}{ Bone mass percentage, $\%$} & $15.00[12.34 ; 17.00]$ & $15.60[13.10 ; 17.00]$ & $15.75[14.80 ; 16.48]$ \\
\hline & \multicolumn{3}{|c|}{$H=7.411 ; P=0.025$} \\
\hline
\end{tabular}

The anthropometric indices of Russian women, in contrast to those of Yakut women of the same age group, differed depending on the type of sexual dimorphism, indicating that they had reached the definitive dimensions of the anthropometric parameters of the body. Our data showed that $\mathrm{BL}$ and $\mathrm{BW}$ were significantly greater in Russian women with the andromorphic type of physique compared to women with the gynomorphic and mesomorphic body types $(P<0.001)$. The shoulder diameter in the subjects with andromorphic type was greater than in women with other types of physique.

The presence of features of anthropometric indices that depend on the type of sexual dimorphism has been demonstrated in the works of other authors. ${ }^{(5,14)}$ There were statistically significant differences in BW in women with an extreme degree of inversion in the form of andromorphy in the absence of significant differences in BL, compared to women with gynomorphic and mesomorphic body types.

Women with a gynomorphic body type had smaller BW compared to those of other types of sexual dimorphism on the background of statistically insignificant differences in BL. Indicators of the body composition in women with gynomorphy were also significantly smaller.

\section{Conclusion}

The anthropometric study revealed that the overall body sizes and indices of the body composition of Yakut girls and young women of different body types according to ISD did not differ significantly, but in Russians, these indices had significant differences according to the body types. The data obtained, depending on the type of sexual dimorphism, indicate the different maturation rates of the morphofunctional structures in Yakut and Russian women in the extreme natural climatic conditions of Yakutia.

\section{Competing interests}

The authors declare that they have no competing interests.

\section{References}

1. Sheldon WH, Stevens SS, Tucker WB. The varieties of human physique an introduction to constitutional psychology. The 1st Ed. New York: Harper \& Brothers; 1940.

2. TANNER JM. Current advances in the study of physique. 
Photogrammetric anthropometry and an androgyny scale. Lancet. 1951;1(6654):574-9.

3. Gorodkova EV, Litvinova TA. [Features of Physical Development of Women-Students in Age Aspect]. Vestnik Novikh Meditsinskikh Tekhnologii. 2009;16(4):64-6. [Article in Russian].

4. Firsova IV, Tretyakova KV. [Age-related changes in the anthropometric parameters of the body and head of Saratov women]. Morphology. 2009; 136(4):143-4. [Article in Russian] 5. Gladkaya VS, Medvedeva NN. [Characteristics of the physical development of women of adolescence living in the Republic of Khakassia]. Sovremennye problemy nauki i obrazovaniya.2016;(6):165. [Article in Russian].

6. Uchakina RV, Filippova VV, Solov'eva MI, Kozlov VK. [Physical and sexual development of girls living in different ecological zones of Priamurye and Yakutia]. Bulletin Physiology and Pathology of Respiration. 2004;19:4246. [Article in Russian].

7. Guryeva AB, Alekseeva VA. [Ethno-constitutional features of the formation of menstrual function in girls in the central region of the Republic of Sakha (Yakutia)]. Fundamentalnie issledovaniia. 2013;11(1):48-50. [Article in Russian].

8. Guryeva AB, Alekseyeva VA, Petrova PG. Characteristics of the anthropometric measures and biological age of girls of Yakut ethnicity depending on tanner's index. Wiad Lek. 2016;69(3 pt 2):471-474.

9. Bunak VV. Anthropometry: a practical course. M.: State Educational and pedagogical Publishing House of the Ministry of Education of the RSFSR; 1941.

10. Issaakson B. A simple formula for the mental arithmetic of human body surface area. Scand J Clin Lab Invest.
1958;10(3):283-9.

11. Matiegka J. The testing of physical efficiency. Am J Phys Anthropol. 1921;4(3):223-230.

12. Tanner JM. Education and Physical growth. London: University of London Press; 1961.

13. Artyukhov IP, Gorbach NA, Lisnyak MA. [Human capital and health: the formulation of the problem]. Sibirskoe meditsinskoe obozrenie. 2008; 49(1): 3-9. [Article in Russian]. 14. Lopatina LA, Serezhenko NP, Anokhin ZhA. Anthropometric characteristics of girls according to the classification of J. Tanner. Fundamentalnie issledovaniia. 2013; 12(3):504-8. [Article in Russian].

15. Trolukova AN, Trolukova EN, Uvarova EV. [Features of physical development and puberty of girls living in extreme natural and climatic conditions of the Republic of Sakha (Yakutia)]. Pediatric and adolescent reproductive health. 2012; 1: 76-88. [Article in Russian].

16. Yusupov RD, Nikolaev VG, Sindeeva LV, Alyamovsky VV, Kazakova GN, Anisimov MM. [Ethnic features of somatometric and kefalometric parameters of women in Eastern Siberia]. Fundamentalnie issledovaniia. 2013; 7 (1): 207-212. [Article in Russian].

17. Nikolaev VG, Sindeeva LV, Nikolenko VN, Kazakova GN, Gur'eva AB. [Peculiarities of the physical development of women in different climatogeographic zones of the Russian Federation]. Sovremennye problemy nauki i obrazovaniya. 2015; 3: 218. [Article in Russian].

18. Kolokoltsev MM, Zver'kova VA. [Features of the manifestation of motor qualities in the students of the university with the Tanner index taken into account]. Sovremennye problemy nauki i obrazovaniya. 2016;6:383. [Article in Russian]. 